\title{
Electronic effect of diphosphines on the regioselectivity of the Pd-catalyzed hydroesterification of styrene
}

\author{
Ester Guiu ${ }^{\mathrm{a}}$, Maria Caporali ${ }^{\mathrm{a}}$, Bianca Muñoz ${ }^{\mathrm{b}}$, Christian Müller $^{\mathrm{a}}$, Martin Lutz ${ }^{\mathrm{c}}$, \\ Anthony L. Spek ${ }^{\mathrm{c}}$, Carmen Claver ${ }^{\mathrm{b}}$ and Piet W. N. M. van Leeuwen ${ }^{\mathrm{a} *}$
}

a. Department of Chemical Engineering and Chemistry, Schuit Institute of Catalysis, Technische Universiteit Eindhoven, P.O. Box 513, 5600 MB Eindhoven, The Netherlands. Fax: +31 40245 5054; Tel: +31 40247 3040; E-mail: p.w.n.m.v.leeuwen@tue.nl

b. Departament de Química Física i Inorgànica, Universitat Rovira i Virgili, Marcel.li Domingo s/n 43007 Tarragona, Spain.

c. Bijvoet Center for Biomolecular Research, Crystal and Structural Chemistry, Utrecht

University, Padualaan 8, 3584 CH Utrecht, The Netherlands

\section{Supporting Information}

\section{Experimental section}

General Considerations: All reactions were carried out in an argon atmosphere using standard Schlenk techniques or in a Braun glovebox unless otherwise stated. All glassware was dried by heating under vacuum. The solvents and TMEDA (N,N,N',N'tetramethylethylenediamine) were dried and distilled prior to use. The reacting gas, carbon monoxide (purity: 99.97\%) was used without purification.

The elemental analyses were obtained from H. Kolbe, Mikroanalytisches Laboratorium, Mülheim (Germany).

${ }^{1} \mathrm{H},{ }^{13} \mathrm{C}\left\{{ }^{1} \mathrm{H}\right\}$ and ${ }^{31} \mathrm{P}\left\{{ }^{1} \mathrm{H}\right\}$ NMR spectra were recorded on a Varian Gemini spectrometer at 200 and $400 \mathrm{MHz}$. Chemical shifts are reported relative to tetramethylsilane for ${ }^{1} \mathrm{H}$ and ${ }^{13} \mathrm{C}\left\{{ }^{1} \mathrm{H}\right\}$ as internal reference and to $\mathrm{H}_{3} \mathrm{PO}_{4} 85 \%$ for ${ }^{31} \mathrm{P}\left\{{ }^{1} \mathrm{H}\right\}$. Melting points were 
measured with an open capillary tube with a Büchi B-540 melting point apparatus and are uncorrected.

High pressure reactions were carried out in a home-made stainless steel autoclave (100 $\mathrm{mL}$ ), equipped with a magnetic stirrer. GC measurements were performed on a Shimadzu 17A chromatograph (split/splitless injector, equipped with a $50 \mathrm{~m}$ ULTRA column and with a F.I.D.). GC-MS measurements (E.I. detection) were perfumed on a HP 5890/5971 apparatus, equipped with a ZB-5 column (5\% cross-linked phenyl polysiloxane) with an internal diameter of $0.25 \mathrm{~mm}$ and film thickness of $0.25 \mu \mathrm{m}$. The mass characterization of palladium complexes has been performed by externally calibrated positive mode reflection MALDI-TOF using a Micromass TofSpec 2E-C equipped with a $2 \mathrm{GHz}$ digitizer. The sample were diluted in ethylacetate, mixed with a concentrated solution of DHB in ethylacetate, and spotted directly on the stainless steel MALDI target.

IR spectra were recorded on a Shimadzu 7300 FT-IR spectrometer.

\section{a) Preparation of the ligands}

\section{Scheme 1}

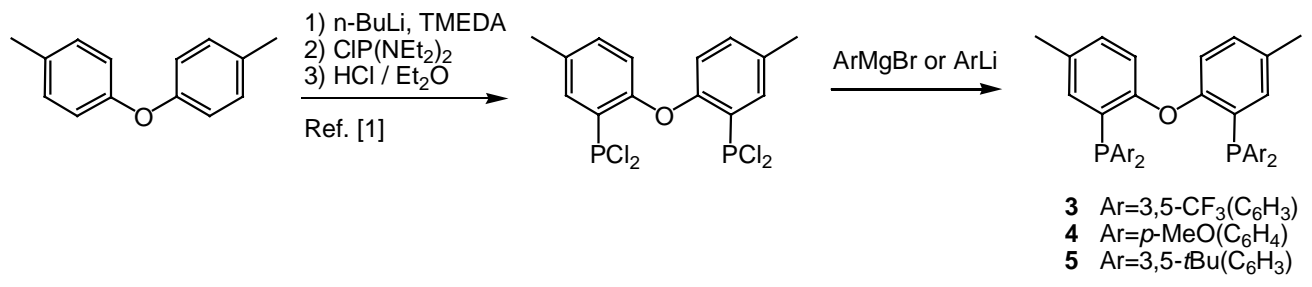

\section{Synthesis of 2,2'-bis(di-(3,5-trifluorophenyl)phosphino)-4,4'-dimethyl-diphenylether}

2,2'-bis(dichlorophosphino)-4,4'-dimethyl-diphenylether was prepared according to combined procedures reported in literature. ${ }^{[1]}$

Magnesium turnings $(0.573 \mathrm{~g}, 23.7 \mathrm{mmol})$ were placed in a flask with $2 \mathrm{~mL}$ of diethyl ether. A small portion of the 3,5-bistrifluoromethyl-bromobenzene $(0.120 \mathrm{~mL})$ was added under slow stirring. When the mixture turned turbid, the remaining solvent $(5 \mathrm{~mL}$ of $\left.\mathrm{Et}_{2} \mathrm{O}\right)$ was added and the bromobenzene $(3.74 \mathrm{~mL}, 21.74 \mathrm{mmol})$ dissolved in diethyl ether 
$(25 \mathrm{~mL})$ was added. The mixture turned dark brown to black during the reaction. After 1.5 hours the dark suspension was used in the next synthesis step.

A flask containing an addition funnel was charged with $1.42 \mathrm{~g}$ (3.55 mmol) of 2,2'bis(dichlorophosphino)-4,4' -dimethyl-diphenylether and $20 \mathrm{~mL}$ of THF and cooled down to $0^{\circ} \mathrm{C}$. The Grignard reagent was added dropwise during an hour. The reaction mixture was slowly warmed up to room temperature and stirred for one hour, then it was hydrolyzed with $5 \mathrm{~mL}$ of water and the solvent was removed in vacuo. The resulting residue was dissolved in $\mathrm{CH}_{2} \mathrm{Cl}_{2}$ and washed with diluted $\mathrm{HCl}$. The organic layer was separated and the aqueous layer extracted with $\mathrm{CH}_{2} \mathrm{Cl}_{2}$. The combined organic layers were dried with $\mathrm{MgSO}_{4}$ and the solvent removed in vacuo. The resulting brown residue was washed with hexane and crystallized from $\mathrm{CH}_{2} \mathrm{Cl}_{2} / \mathrm{MeOH}$.

Yield: $46 \%$. M.p. $152^{\circ} \mathrm{C} . \delta_{\mathrm{H}}\left(\mathrm{CDCl}_{3}, 400 \mathrm{MHz}\right) 7.83$ (br s, $4 \mathrm{H}$ ar), 7.62 (br s, $8 \mathrm{H}$ ar), 7.16 (br s, 2H, ar), 6.65 (br s, $2 \mathrm{H}$ ar), 6.51 (br s, $2 \mathrm{H}$ ar), 2.21 (s, 6H, $\left.\mathrm{CH}_{3}\right) . \delta_{\mathrm{C}}(100.6 \mathrm{MHz}$, $\left.\mathrm{CDCl}_{3}\right) 156.6$ (d, J=17.7Hz, C ar), 138.8 (d, J=20.1Hz, CH ar), 135.0 (CH ar), 133.6 (d, $J=22 \mathrm{~Hz}, \mathrm{CH}$ ar), 132.2 (q, $J=33.6 \mathrm{~Hz}, J=66.5 \mathrm{~Hz}, \mathrm{C}$ ar), 127.3 (C ar), 124 (d, J=14.1Hz, C ar), $123.5\left(\mathrm{CH}\right.$ ar), 123.2 (q, J=272.2Hz, $\left.\mathrm{CF}_{3}\right), 118.1\left(\mathrm{CH}\right.$ ar), $20.9\left(\mathrm{CH}_{3}\right) . \delta_{\mathrm{P}}\left(\mathrm{CDCl}_{3}\right.$, 161.9 MHz) -11.7 ppm. $v_{\max }(\mathrm{KBr}) / \mathrm{cm}^{-1} 2979,2895,1613,1461,1355,1275,1168,1119$, 891, 838, 702, 683. Anal.Calcd. for $\mathrm{C}_{46} \mathrm{H}_{24} \mathrm{~F}_{24} \mathrm{OP}_{2}$ : C 49.75, H 2.18. Found: C 49.58, H 2.23 .

\section{2,2'-bis(di-p-anisylphosphino)-4,4'-dimethyl-diphenylether (4)}

2,2'-bis(dichlorophosphino)-4,4'-dimethyl-diphenylether was prepared according to combined procedures reported in lit. ${ }^{[1]}$

A solution of $2.28 \mathrm{~mL}(18.31 \mathrm{mmol})$ of 4-bromo-anisole in $3 \mathrm{~mL}$ of $\mathrm{Et}_{2} \mathrm{O}$ was added dropwise to a stirred mixture of $0.66 \mathrm{~g}$ of magnesium turnings $(27.47 \mathrm{mmol})$ in $8 \mathrm{~mL}$ of THF and $8 \mathrm{~mL}$ of $\mathrm{Et}_{2} \mathrm{O}$ at $0^{\circ} \mathrm{C}$. An iodine crystal was added to facilitate the initiation of the reaction. The reaction mixture was stirred overnight at room temperature. The reaction mixture was transferred into an addition funnel and washed with $20 \mathrm{~mL}$ of THF to ensure that the entire Grignard reagent had been transferred. The flask containing the addition funnel was charged with $1.33 \mathrm{~g}$ (3.33 mmol) of 2,2'-bis(dichlorophosphino)4,4'-dimethyl-diphenylether and $20 \mathrm{~mL}$ of $\mathrm{THF}$ and cooled to $-40^{\circ} \mathrm{C}$ and the Grignard 
reagent was added for 4 hours. The reaction mixture was kept between $-40^{\circ} \mathrm{C}$ and $-20^{\circ} \mathrm{C}$ and stirred for $1 \mathrm{~h}$. The resulting residue was dissolved in $\mathrm{CH}_{2} \mathrm{Cl}_{2}$ and washed with diluted $\mathrm{HCl}$. The organic layer was separated and the aqueous layer extracted with $\mathrm{CH}_{2} \mathrm{Cl}_{2}$. The combined organic layers were dried with $\mathrm{MgSO}_{4}$ and the solvent removed in vacuo. The resulting pale yellow residue was purified by a short filtration over silica gel $\left(\mathrm{CH}_{2} \mathrm{Cl}_{2}\right)$. Yield: $25 \%$. M.p. $198^{\circ} \mathrm{C} . \delta_{\mathrm{H}}\left(\mathrm{CDCl}_{3}, 400 \mathrm{MHz}\right) 7.14\left(\mathrm{t},{ }^{3} \mathrm{~J}=8 \mathrm{~Hz}, 8 \mathrm{H}\right.$ ar), 6.96 $\left(\mathrm{dd}, J m e t a=1.6 \mathrm{~Hz},{ }^{3} \mathrm{~J}_{\mathrm{HP}}=8.4 \mathrm{~Hz}, 2 \mathrm{H}\right.$ ar), 6.78 (d, Jortho=8.8Hz, $8 \mathrm{H}$ ar), 6.57-6.54 (m, 4H ar), $3.79\left(\mathrm{~s}, 12 \mathrm{H}, \mathrm{CH}_{3} \mathrm{O}\right), 2.15\left(\mathrm{~s}, 6 \mathrm{H}, \mathrm{CH}_{3}\right) . \delta_{\mathrm{C}}\left(100.6 \mathrm{MHz}, \mathrm{CDCl}_{3}\right) 160.1(\mathrm{C}$ ar), 157.5 (d, $J=16.7 \mathrm{~Hz}, \mathrm{C}$ ar), 135.4 (d, $J=22.0 \mathrm{~Hz}, \mathrm{CH}$ ar), $134.1(\mathrm{CH}$ ar), $132.8(\mathrm{CH}$ ar), 130.8 (C ar), $129.5(\mathrm{~d}, J=15.2 \mathrm{~Hz}, \mathrm{C}$ ar), $128.2(\mathrm{~d}, J=8.3 \mathrm{~Hz}, \mathrm{C}$ ar), $118.2(\mathrm{CH}$ ar), 114.1 (d, $J=7.5 \mathrm{~Hz}, \mathrm{CH}$ ar), $55.3\left(\mathrm{CH}_{3} \mathrm{O}\right), 21.0\left(\mathrm{CH}_{3}\right) . \delta_{\mathrm{P}}\left(\mathrm{CDCl}_{3}, 161.9 \mathrm{MHz}\right)-18.9 . v_{\max }(\mathrm{KBr}) / \mathrm{cm}^{-}$ ${ }^{1}$ 2956, 2895, 1590, 1491, 1460, 1244, 1172, 1093, 1021, 792.

\section{2,2'-bis(di-3,5-tertbutylphosphino)-4,4'-dimethyl-diphenylether (5) ${ }^{[1]}$}

2,2'-bis(dichlorophosphino)-4,4'-dimethyl-diphenylether was prepared according to the procedure reported in lit. ${ }^{[1]}$

1-bromo-3,5-di-tert-butylbenzene was prepared according to the procedure reported in lit. $^{[2]}$

\section{Scheme 2}

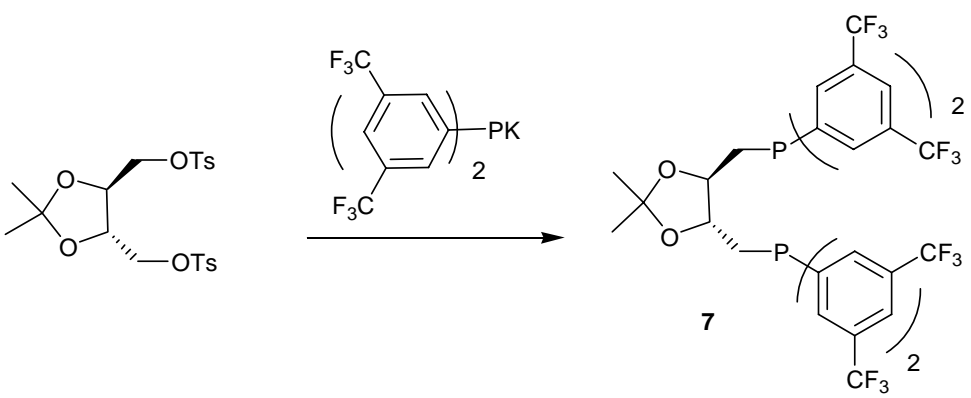

trans-4,5-[[bis(3,5-ditrifluoromethylphenyl)phosphino-2,2-dimethyl-1,3-dioxolane $(7)^{[3]}$

This ligand was prepared following a modification of procedures reported in the literature $^{[3]}$. 
A solution of $1.07 \mathrm{~g}$ (2.33 mmol) of bis(3,5-ditrifluoromethylphenyl)phosphine in $2.5 \mathrm{~mL}$ of dry tetrahydrofuran was added dropwise in a mixture of $\mathrm{KH}$ (98 mg; $2.39 \mathrm{mmol}$ ) deoiled in tetrahydrofuran $(0.5 \mathrm{~mL})$ previously cooled to $-78^{\circ} \mathrm{C}$ over a period of 15 minutes. The dark red solution was stirred at $-78^{\circ} \mathrm{C}$ for an aditional 20 minutes, then warmed to $25^{\circ} \mathrm{C}$. After stirring at $25^{\circ} \mathrm{C}$ for $5 \mathrm{~min}$, the reaction mixture was re-cooled to $78^{\circ} \mathrm{C}$ and a solution of (S,S)-trans-4,5-bis[(p-tosyloxy)methyl]-2,2-dimethyl-1,3dioxolane $(549.8 \mathrm{mg} ; 1.16 \mathrm{mmol})$ in $3 \mathrm{~mL}$ of tetrahydrofuran was slowly added. The resulting mixture was stirred at $-78^{\circ} \mathrm{C}$ for $15 \mathrm{~min}$. After warming to $25^{\circ} \mathrm{C}$ the mixture was stirred for 5 hours when the reaction finished (checked by ${ }^{31} \mathrm{P}\left\{{ }^{1} \mathrm{H}\right\} \mathrm{NMR}$ ). The solvent was evaporated under reduced pressure and the residue was dissolved in degassed $\mathrm{Et}_{2} \mathrm{O}$ $(15 \mathrm{~mL})$. The solution was washed with degassed water $(4 \times 5 \mathrm{~mL})$. The organic layer was separated, dried $\left(\mathrm{MgSO}_{4}\right)$ and solvent was evaporated under reduced pressure to give a brown solid material. The product was purified by crystallization with dichloromethane/hexane. Yield: $605 \mathrm{mg}$ white solid $(50 \%) . \delta_{\mathrm{H}}\left(\mathrm{CDCl}_{3}, 400 \mathrm{MHz}\right) 7.87$ (m, 12H, arom.), $4.05(\mathrm{~m}, 2 \mathrm{H}, \mathrm{OCH}), 2.42\left(\mathrm{~m}, 4 \mathrm{H}, \mathrm{CH}_{2}\right), 1.26\left(\mathrm{~s}, 6 \mathrm{H}, \mathrm{CH}_{3}\right) . \delta_{\mathrm{P}}\left(\mathrm{CDCl}_{3}\right.$, 161.9 MHz) -16.3 (s) ppm. Anal.calcd. for $\mathrm{C}_{39} \mathrm{H}_{24} \mathrm{~F}_{24} \mathrm{O}_{2} \mathrm{P}_{2}$ (1042.53): C, 44.93; H, 2.51 . Found: C, 44.89; H, 2.99. MS (electro spray): m/z 1042.9.

\section{b) Preparation of the Pd-complexes}

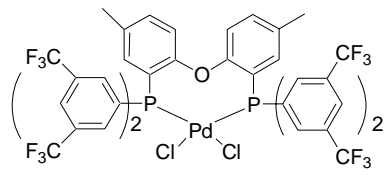

(9)

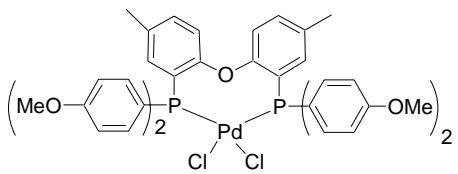

(10)

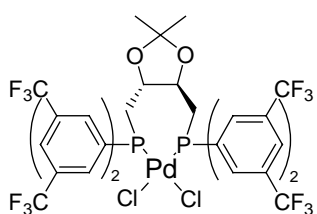

(13)

\section{cis- $\left[\mathrm{PdCl}_{2} 1\right](8)$}

The complex was prepared as reported in lit. ${ }^{[4]}$

cis-[PdCl 3$]$ (9) 
A solution of ligand $3(0.389 \mathrm{mg}, 0.35 \mathrm{mmol})$ in dichloromethane $(5 \mathrm{~mL})$ was added to a stirred solution of $\left[\mathrm{Pd}(\mathrm{COD}) \mathrm{Cl}_{2}\right](0.100 \mathrm{~g}, 0.35 \mathrm{mmol})$ in dichloromethane $(3 \mathrm{~mL})$ at room temperature, and the mixture was stirred for 1 hour. Addition of $\mathrm{Et}_{2} \mathrm{O}$ led to the formation of a yellow precipitate, which was isolated by filtration, washed with $\mathrm{Et}_{2} \mathrm{O}$ and dried in vacuo.

Yield: $74.4 \% . \delta_{\mathrm{H}}\left(\mathrm{CDCl}_{3}, 400 \mathrm{MHz}\right) 8.00(\mathrm{~m}, 11 \mathrm{H}$ ar), $7.26(\mathrm{~m}, 3 \mathrm{H}$ ar), $6.94(\mathrm{~m}, 2 \mathrm{H}$ ar), $6.47\left(\mathrm{~m}, 2 \mathrm{H}\right.$ ar), $2.11\left(\mathrm{~s}, 6 \mathrm{H}, \mathrm{CH}_{3}\right) . \delta_{\mathrm{C}}\left(100.6 \mathrm{MHz}^{\mathrm{CDCl}} \mathrm{CDC}_{3}\right) 157.0(\mathrm{~d}, J=6.84 \mathrm{~Hz}, \mathrm{C}$ ar), 136.7 (CH ar), 136.4 (CH ar), 134.8 (br, $\mathrm{CH}$ ar), 132.0 (br, C ar), 126.7 (C ar), 125.8 (br, $\mathrm{CH}$ ar), 122.6 (q, $\left.J=273 \mathrm{~Hz}, \mathrm{CF}_{3}\right), 122.3$ (br, C ar), 119.3 (C ar), 116.8 (CH ar), 20.7 $\left(\mathrm{CH}_{3}\right) . \delta_{\mathrm{P}}\left(\mathrm{CDCl}_{3}, 161.9 \mathrm{MHz}\right) 20.96(\mathrm{~s}) . v_{\max }(\mathrm{KBr}) / \mathrm{cm}^{-1} 1616,1464,1351,1271,1119$, 683. MS (maldi tof) $\mathrm{m} / \mathrm{z} 1250\left(\mathrm{M}^{+}-\mathrm{Cl}\right)$. Anal.Calcd. for $\mathrm{C}_{46} \mathrm{H}_{24} \mathrm{Cl}_{2} \mathrm{~F}_{24} \mathrm{OP}_{2} \mathrm{Pd}$ : C 42.90, $\mathrm{H}$ 1.88. Found: C 42.76, H 1.89 .

\section{cis-[PdCl $\mathbf{2} 4](10)$}

A solution of ligand $4(0.159 \mathrm{~g}, 0.23 \mathrm{mmol})$ in dichloromethane $(5 \mathrm{~mL})$ was added to a stirred solution of $\left[\mathrm{Pd}(\mathrm{COD}) \mathrm{Cl}_{2}\right](0.060 \mathrm{~g}, 0.21 \mathrm{mmol})$ in dichloromethane $(2 \mathrm{~mL})$ at room temperature, and the mixture was stirred for 1 hour. Addition of $\mathrm{Et}_{2} \mathrm{O}$ led to the formation of a yellow precipitate, which was isolated by filtration, washed with $\mathrm{Et}_{2} \mathrm{O}$ and dried in vacuo.

Yield: $85 \% . \delta_{\mathrm{H}}\left(\mathrm{CDCl}_{3}, 200 \mathrm{MHz}\right) 7.51(\mathrm{~m}, 6 \mathrm{H}$ ar), 7.26-7.07 (m, 4H ar), 6.88-6.75 (m, $10 \mathrm{H}$ ar), $6.53\left(\mathrm{~d}, J=8.4 \mathrm{~Hz}, 2 \mathrm{H}\right.$ ar), $3.79\left(\mathrm{~s}, 12 \mathrm{H}, \mathrm{CH}_{3} \mathrm{O}\right), 2.05\left(\mathrm{~s}, 6 \mathrm{H}, \mathrm{CH}_{3}\right) . \delta_{\mathrm{C}}(50.3$ $\left.\mathrm{MHz}, \mathrm{CDCl}_{3}\right) 161.5$ (C ar), 157.2 (d, J=6.1Hz, C ar), 136.9 (br, CH ar), 135.0 (br, C ar), 133.5 (CH ar), 128.1 (C ar), 123.8 (br, C ar), 121.7 (br, C ar), 120.5 (C ar), 113.5 (d, J = 12.8Hz, $\mathrm{CH}$ ar), $55.5\left(\mathrm{CH}_{3} \mathrm{O}\right), 20.8\left(\mathrm{CH}_{3}\right) . \delta_{\mathrm{P}}\left(\mathrm{CDCl}_{3}, 81 \mathrm{MHz}\right) 18.73(\mathrm{~s}) . v_{\max }(\mathrm{KBr}) / \mathrm{cm}^{-}$

${ }^{1}$ : 1594, 1472, 1347, 1267, 1093, 679. Anal. calcd. for $\mathrm{C}_{42} \mathrm{H}_{40} \mathrm{Cl}_{2} \mathrm{O}_{5} \mathrm{P}_{2} \mathrm{Pd}$ (864.05): C, 58.38; H, 4.67. Found: C, 58.3; H, 4.59. MS (maldi-tof) m/z $829\left(\mathrm{M}^{+}-\mathrm{Cl}\right)$.

cis-[PdCl 25$](11)$

The complex was prepared as reported in lit. ${ }^{[1]}$

cis-[PdCl 27$](13)$ 
A solution of $7(250 \mathrm{mg}, 0.24 \mathrm{mmol})$ in dichloromethane $(2 \mathrm{~mL})$ was added to a stirred solution of $\left[\mathrm{PdCODCl}_{2}\right](65 \mathrm{mg}, 0.23 \mathrm{mmol})$ in dichloromethane $(2 \mathrm{~mL})$ at room temperature, and the mixture was stirred for 1 hour. Addition of $\mathrm{Et}_{2} \mathrm{O}$ led to the formation of a pale yellow precipitate, which was isolated by filtration, washed with $\mathrm{Et}_{2} \mathrm{O}(2 \times 5 \mathrm{~mL})$ and hexane $(1 \times 5 \mathrm{~mL})$ and dried in vacuo. Yield: $180.8 \mathrm{mg}$ pale yellow solid $(64 \%)$. $\delta_{\mathrm{H}}$ (THF-d $\left.{ }_{8}, 400 \mathrm{MHz}\right) 8.34$ (m, 4H, arom.-H), 8.23 (m, 8H, arom.-H), 3.93 (m, 2H, OCH), $3.44\left(\mathrm{~m}, 2 \mathrm{H}, \mathrm{CH}_{2}\right), 2.92(\mathrm{~m}, 2 \mathrm{H}, \mathrm{CH} 2), 1.21\left(\mathrm{~s}, 6 \mathrm{H}, \mathrm{CH}_{3}\right) . \delta_{\mathrm{P}}\left(\mathrm{CDCl}_{3}, 161.9 \mathrm{MHz}\right) 20.78$ ppm (s). Anal. Calcd for $\mathrm{C}_{39} \mathrm{H}_{24} \mathrm{Cl}_{2} \mathrm{~F}_{24} \mathrm{O}_{2} \mathrm{P}_{2} \mathrm{Pd}$ (1219.85): C, 38.40; H, 1.98. Found: C, 38.29; H, 2.41. MS (malditof) m/z $1184\left(\mathrm{M}^{+}-\mathrm{Cl}\right)$.

\section{cis-[Pd( $\left.\left.\mathrm{CH}_{3}\right) \mathrm{Cl}(3)\right](14)$}

A solution of ligand $3(60 \mathrm{mg}, 0.12 \mathrm{mmol})$ in $3 \mathrm{~mL}$ of dichloromethane was added to a stirred solution of $(\mathrm{COD}) \mathrm{Pd}\left(\mathrm{CH}_{3}\right) \mathrm{Cl}(31.8 \mathrm{mg}, 0.12 \mathrm{mmol}$, prepared as in lit. [5]) in $2 \mathrm{~mL}$ of dichloromethane at room temperature. The reaction mixture was stirred for two hours under argon, then the solvent was evaporated and the residue was washed with hexane. Yellow microcrystals were isolated. Yield: $90 \%$.

$\delta_{\mathrm{H}}\left(\mathrm{CDCl}_{3}, 400 \mathrm{MHz}\right) 8.1\left(\mathrm{~m}, 6 \mathrm{H}\right.$ ar), 7.86 (br s, 2H ar), 7.44 (m, 5H ar), 7.1 (dd, $J_{\mathrm{HH}}=$ $8.2,5.6 \mathrm{~Hz}, 1 \mathrm{H}$ ar), $6.80\left(\mathrm{~d}, J_{\mathrm{HH}}=8.2 \mathrm{~Hz}, 1 \mathrm{H}\right.$ ar), 6.69 (d, $\mathrm{J}_{\mathrm{HH}}=7.4 \mathrm{~Hz}, 1 \mathrm{H}$ ar), 6.24 (dd, $J_{\mathrm{HH}}=8.2,5 \mathrm{~Hz}, 1 \mathrm{H}$ ar), $5.92\left(\mathrm{~d}, J_{\mathrm{HH}}=10.6 \mathrm{~Hz}, 1 \mathrm{H}\right.$ ar), $2.3\left(\mathrm{~s}, 6 \mathrm{H}, \mathrm{CH}_{3}\right), 1.22(\mathrm{~m}, 3 \mathrm{H}, \mathrm{Pd}-$ $\left.\mathrm{CH}_{3}\right) . \delta_{\mathrm{C}}\left(100.6 \mathrm{MHz}, \mathrm{CDCl}_{3}\right) 157.4(\mathrm{~d}, J=6.5 \mathrm{~Hz}, \mathrm{C}$ ar), 156 (d, $J=11.9 \mathrm{~Hz}, \mathrm{C}$ ar), 137.5 (d, $J=4.2 \mathrm{~Hz}, \mathrm{C}$ ar), 135.8 (s, CH ar), 134.8 (s, CH ar), 133.8 (br s, CH ar), 132.4 (br s, $\mathrm{C}$ ar), 125.7 (br s, C ar), 124.1 (br s, C ar), 122.2 ( $\mathrm{CH}$ ar), 122.5 (q, ${ }^{1} \mathrm{~J}_{\mathrm{CF}}=273.5 \mathrm{~Hz}, \mathrm{CF}_{3}$ ), 118.5 (d, J=4.6 Hz, CH ar), $20.9\left(\mathrm{CH}_{3}\right), 0.99\left(\mathrm{~s}, \mathrm{Pd}-\mathrm{CH}_{3}\right) \delta_{\mathrm{P}}\left(\mathrm{CDCl}_{3}, 80.9 \mathrm{MHz}\right) 31.4$ (d,

$\left.{ }^{2} \mathrm{~J}_{\mathrm{PP}}=30.3 \mathrm{~Hz}\right), 11.05\left(\mathrm{~d},{ }^{2} \mathrm{~J}_{\mathrm{PP}}=30.3 \mathrm{~Hz}\right) \cdot v_{\max }(\mathrm{KBr}) / \mathrm{cm}^{-1} 2982,2903,1619,1465,1358$, 1275, 1184, 1144, 895, 839, 703, 681. MS (maldi-tof) m/z $1232.90\left(\mathrm{M}^{+}-\mathrm{Cl}\right)$. This compound was further characterized by X-ray diffraction (vide infra).

\section{Crystal structure determination of (14).}

$\mathrm{C}_{47} \mathrm{H}_{27} \mathrm{ClF}_{24} \mathrm{OP}_{2} \mathrm{Pd}+$ disordered solvent, $\mathrm{Fw}=1267.48$ [*], yellow needle, $0.60 \mathrm{x} 0.24 \mathrm{x}$ $0.18 \mathrm{~mm}^{3}$, orthorhombic, $\mathrm{P} 22_{1} 2_{1}$ (no. 19), $\mathrm{a}=10.27233(10), \mathrm{b}=17.92498(9), \mathrm{c}=$ 
29.46355(19) $\AA, V=5425.16(7) \AA^{3}, Z=4, D_{x}=1.552 \mathrm{~g} / \mathrm{cm}^{3}$ [*]. X-ray intensities were measured on a Nonius Kappa CCD diffractometer with rotating anode and graphite monochromator $(\lambda=0.71073 \AA)$ up to a resolution of $(\sin \theta / \lambda)_{\max }=0.65 \AA^{-1}$ at a temperature of 150(2) K. 94092 Reflections were measured. An absorption correction based on multiple measured reflections was applied $\left(\mu=0.567 \mathrm{~mm}^{-1}[*], 0.72-0.90\right.$ correction range). 12465 reflections were unique $\left(\mathrm{R}_{\text {int }}=0.0278\right)$. The structure was solved with direct methods [6] and refined with SHELXL-97 [7] on $\mathrm{F}^{2}$ of all reflections. Non hydrogen atoms were refined with anisotropic displacement parameters. Hydrogen atoms were introduced in geometrically idealized positions and refined with a riding model. The $\mathrm{CF}_{3}$ groups at $\mathrm{C} 47$ and $\mathrm{C} 67$ were refined with a disorder model. The crystal structure contains large voids (802.9 $\AA^{3} /$ unit cell) filled with disordered solvent molecules. Their contribution to the structure factors was secured by back-Fourier transformation using the SQUEEZE routine of the PLATON program [8] resulting in 86 electrons / unit cell. 742 parameters were refined with 270 restraints. R1/wR2 [I > $2 \sigma(\mathrm{I})]$ : 0.0253/0.0616. R1/wR2 [all refl.]: 0.0297/0.0635. $\mathrm{S}=1.067$. Flack parameter [9] $\mathrm{x}=$ $-0.033(14)$. Residual electron density between -0.26 and 0.51 e/A $\AA^{3}$. Geometry calculations, drawings and checking for higher symmetry were performed with the PLATON package [8].

[*] derived parameters do not contain the contribution of the disordered solvent.

\section{General procedure for the hydroesterification of styrene.}

Into a stainless steel autoclave and under argon were placed a degassed mixture of the corresponding palladium complex $(0.015 \mathrm{mmol})$, styrene $(3 \mathrm{mmol})$, anhydrous $\mathrm{MeOH}$ (30 mmol), anhydrous $\mathrm{HCl}$ in an ethereal solution $2 \mathrm{M}(3 \mathrm{mmol})$ and $5 \mathrm{~mL}$ of toluene. The autoclave was then flushed three times with 5 bar of $\mathrm{CO}$ and then pressurized with 70 bar of $\mathrm{CO}$. The reaction was allowed to proceed with stirring at $100^{\circ} \mathrm{C}$ for 16 hours. The reaction mixture was analyzed by GC using acetophenone $(5 \mathrm{mmol})$ as internal standard. 


\section{References}

[1] Caporali M., Müller C., Staal B.B.P, Tooke D.M., Spek A.L., van Leeuwen P.W.N.M., Chem. Commun., 2005, 3478-3480.

[2] Komen C.M.D., Bickelhaupt F., Synthetic Communication, 1996, 26(9), 16931697.

[3] a) McKinstry L., Livinghouse T., Tetrahedron 1994, 21, 6145-6154. b) Hobbs C.F., Knowles W.S, J. Org. Chem. 1981, 46, 4422.

[4] Kranenburg M., Kamer P.C.J., van Leeuwen P.W.N.M., Eur.J.Inorg.Chem., 1998, 155-157.

[5] Ladipo F.T., Anderson G.K, Organometallics, 1994, 13, 303.

[6] Altomare A., Burla M.C., Camalli M., Cascarano G.L., Giacovazzo C., Guagliardi A., Moliterni A.G.G., Polidori G., Spagna R., J. Appl. Cryst. 1999, 32, 115-119.

[7] Sheldrick G.M. (1997). SHELXL-97. Program for crystal structure refinement. Universität Göttingen, Germany.

[8] Spek A.L., J. Appl. Cryst. 2003, 36, 7-13.

[9] Flack H.D., Acta Cryst. 1983, A39, 876-881.

\section{Attachment: ${ }^{1} \mathrm{H},{ }^{31} \mathrm{P}$ and ${ }^{13} \mathrm{C}$ NMR of ligand 4}



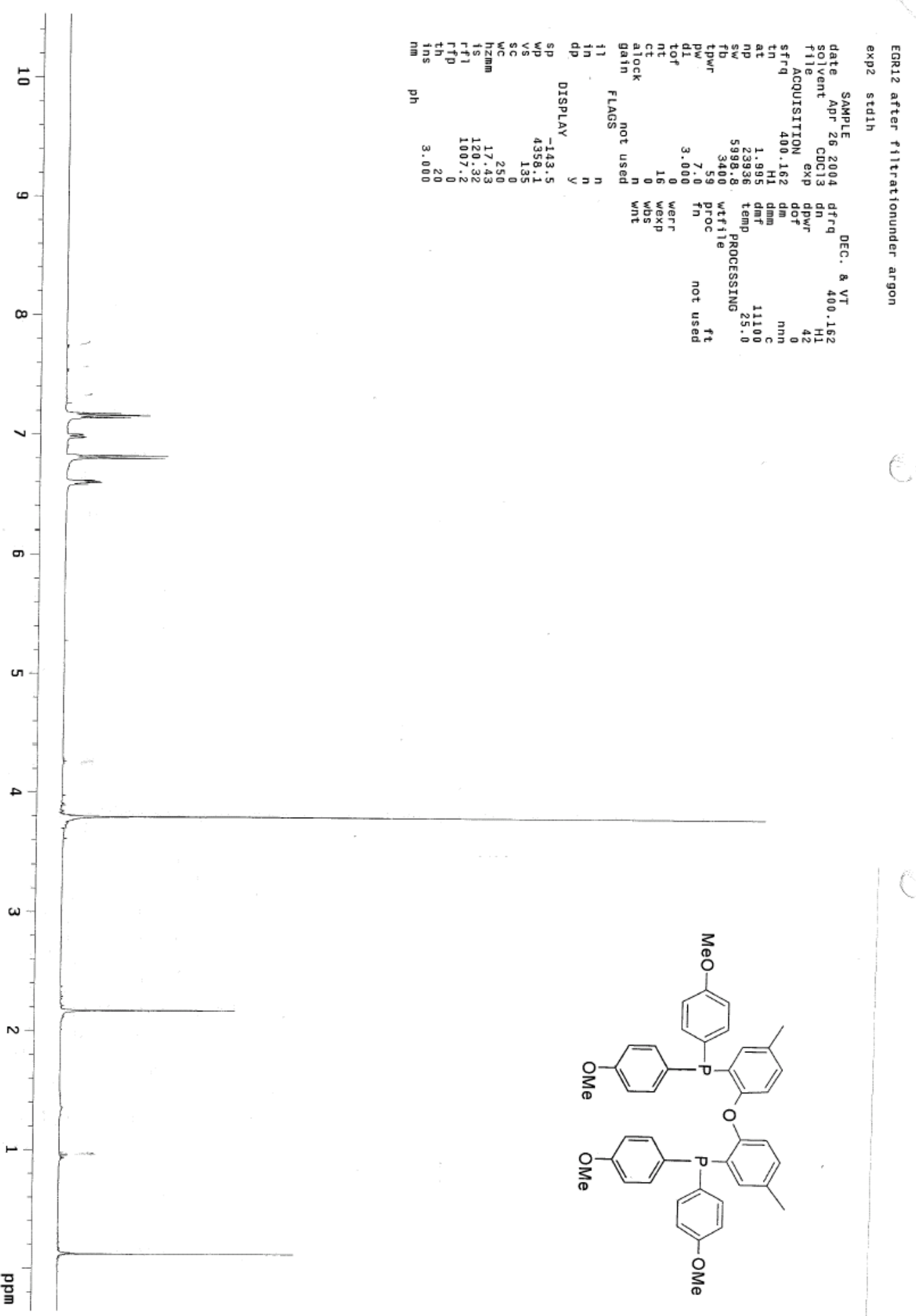


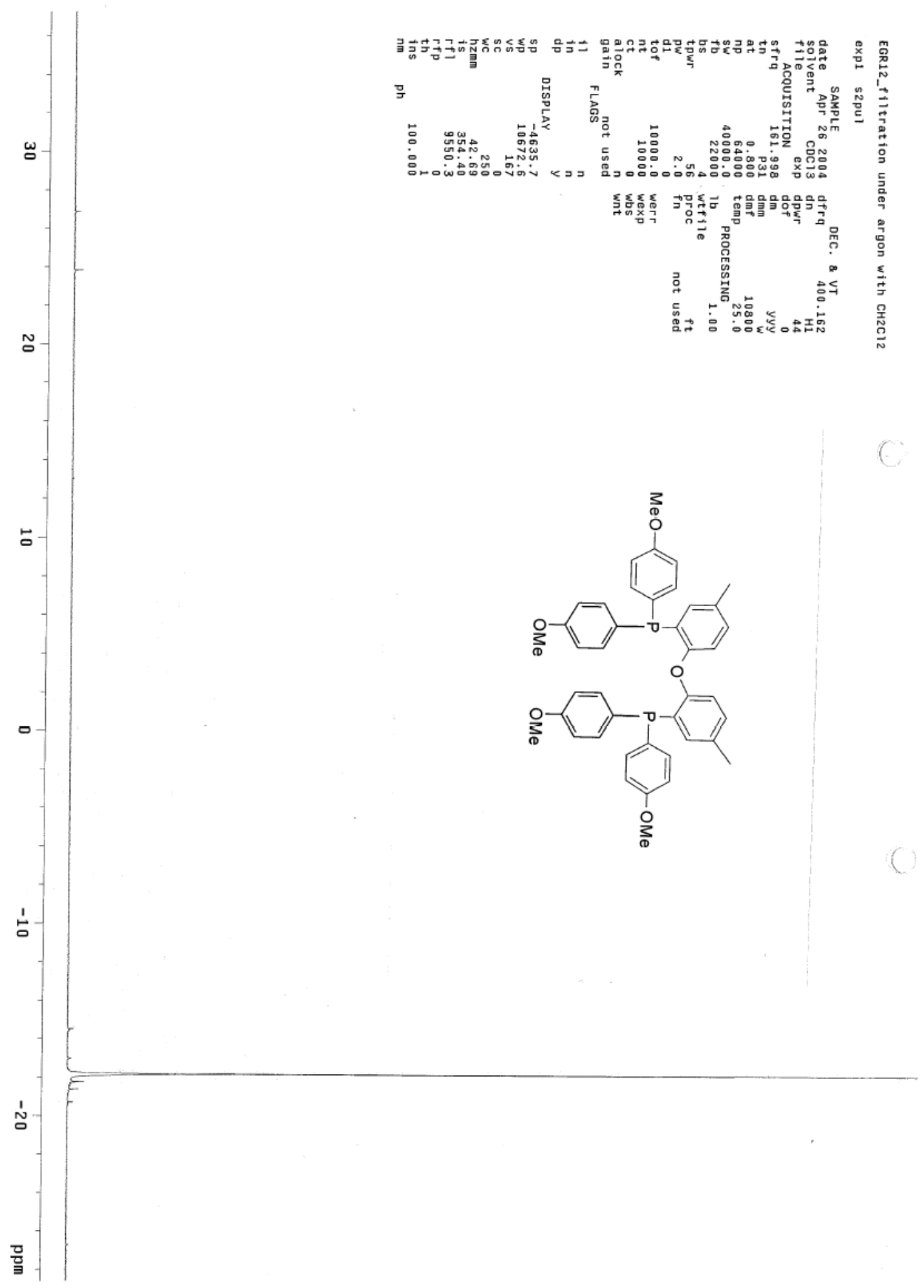



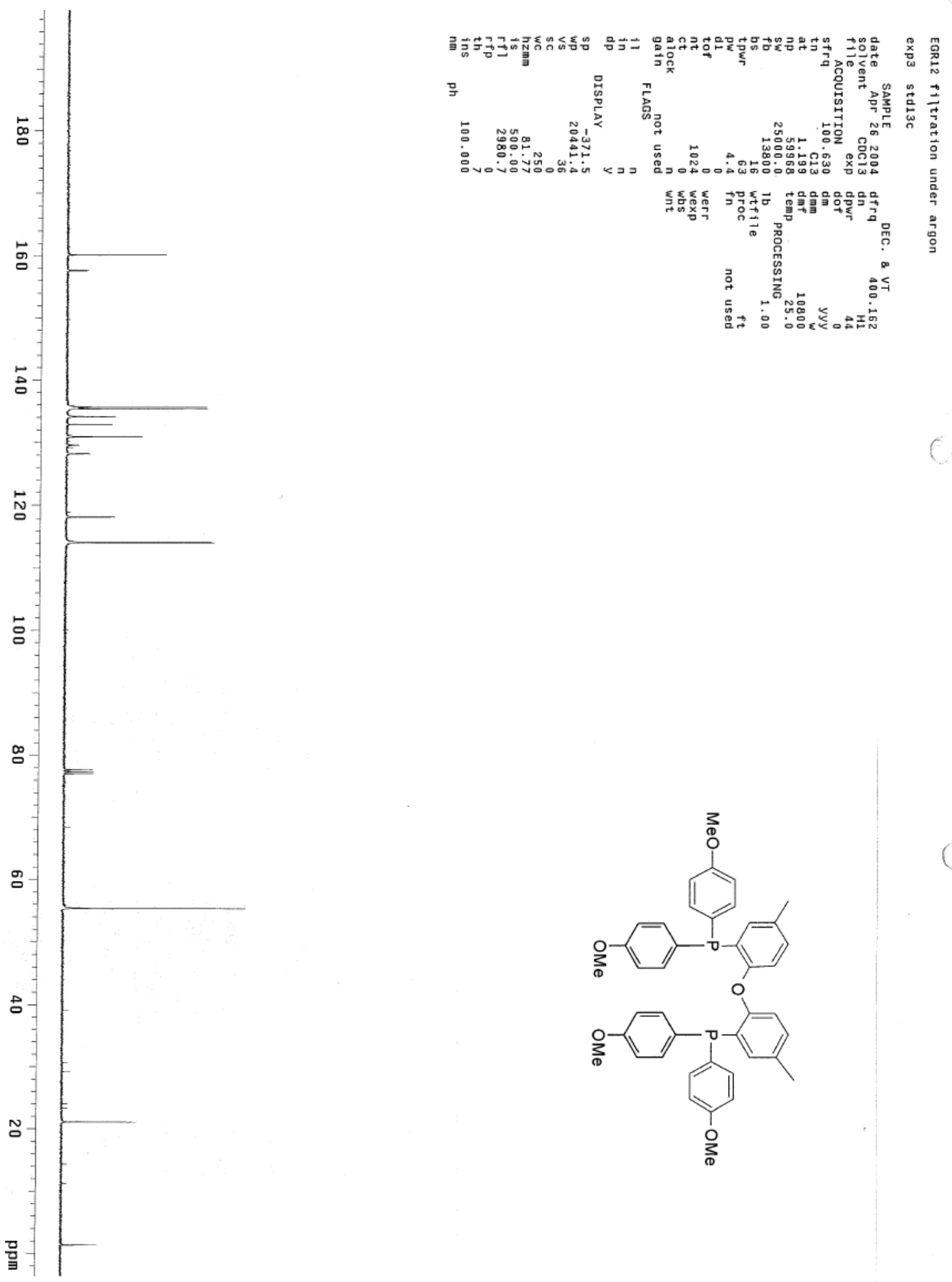